\title{
Why do Authoritarian Leaders do Regionalism? Ontological Security and Eurasian Regional Cooperation
}

\author{
Alessandra Russo and Edward Stoddard \\ Sciences Po Bordeaux and University of Portsmouth \\ Email corresponding author: alessandra.russo@sssup.it Twitter : @alessandra russ
}

\begin{abstract}
:
Collective ontological security refers to the psychological human need to be part of a stable collective identity. Populations expect leaders to help meet these ontological needs and support those that do. In the Eurasian region, and in addition to other objectives, Russian and Kazakh presidents have used regional cooperation efforts as an elite-led strategy of ontological security building and reinforcement - especially important as national identities were contested and weak after the collapse of the Soviet Union. Focusing on ontological security presents a novel research perspective on Eurasian regionalism and offers a new (but complementary) explanation of both autocratic regional cooperation and conflict.
\end{abstract}

\section{Keywords: Eurasian Economic Union, regionalism, ontological security, Russia, Kazakhstan}

Acknowledgements: We presented earlier versions of the paper at the IR Research Colloquium (3 March 2016, University of Oxford) as well as at the II Workshop "Regionalism and Identities in the Post-Soviet Areas: Actors and Processes after the Ukrainian Crisis" (26-27 October 2017, Sciences Po Bordeaux). We would like to thank the organisers and the participants of those events for the constructive discussions. We are grateful for comments from Neil MacFarlane, Fuadi Pitsuwan, Caroline Dufy, Daniel Bach, Babatunde Fagbayibo, Angela Crack, Elin Hellquist.

The last three decades have witnessed a marked growth in regional organisations across the globe - including in regions, such as Eurasia, characterised by authoritarianism. ${ }^{1}$ Overall however, inter-authoritarian regionalism, beset by neo-patrimonial structures unsuited to the political and economic liberalisation that regionalism has often promised, has delivered mixed results when compared with its democratic counterparts. ${ }^{2}$ Scholars have sought to explain this authoritarian paradox of 'virtual regionalism' (continued regional cooperation despite limited functional output) through a focus on the links between regional

\footnotetext{
${ }^{1}$ Buzan and Wæver, Regions and Powers, 3; Börzel, Comparative Regionalism, 8; Fawcett and Gandois, "Regionalism in Africa".

${ }^{2}$ Collins, "Economic and Security Regionalism" 250; Kirschner and Stapel, "Does Regime Type Matter?", 147.
} 
cooperation and the informal, and to some extent non-material, authoritarian 'regimeboosting' benefits of regionalism. ${ }^{3}$ Indeed, academics have identified how regional cooperation can help support autocratic regimes through a mixture of copying internationally legitimate/Western practices, faking other Western practices (such as election monitoring), delegitimising Western actors and rejecting their democratisation efforts, and offering material support to autocrats in the face of regime threats.

This article builds on these observations, demonstrating an alternative (but complementary) informal and non-material driver of elite-led regional cooperation in Eurasia. It is based on the phenomenon of 'collective ontological security', ${ }^{4}$ which refers to the psychological need of human social groups to have a stable and secure collective identity. Just like physical security, most people have a profound desire for security and stability with regard to their identity and consider threats to this identity (that is, threats to their ontological security) as stressful and destabilising. ${ }^{5}$ Collective identity, the identity we personally derive from and share with the main social groups we belong to, is an important component of an individual's sense of identity. As such, groups of people who share a common identity experience common angst when the collective ontological security of this identity is threatened. Ontologically secure individuals or groups are thus those who are secure of their identity, and confident that they do not face major challenges to the reproduction of this identity over time. ${ }^{6}$

For many (most ?) people, national identity is the most important collective identity and it is considered the most important in the context of this article. Unlike many other aspects of our individual identity, key aspects of national identity (such as national pride, the reinforcement of collective past glories or injustices, a sense of national direction/progress, etc.) are both largely beyond the control of an individual and require cultivation by political leaders.

\footnotetext{
3 Allison, "Virtual Regionalism, Regional Structures", 185; Söderbaum, "With a Little Help", 7; Collins, Economic and Security Regionalism", 250; Bohr, "Regionalism in Central Asia", 486-7.

4 Kinnvall, "Globalization and Religious Nationalism"; Mitzen, "Ontological Security in World Politics"; Steele, Ontological Security in International Relations; Croft, "Constructing Ontological Insecurity"; Darwich, The Ontological (In)security of Similarity.

${ }^{5}$ The importance of personal ontological security is well established in the literatures on psychology and psychiatry. See for example Padgett, "There's no place like (a) home".

${ }^{6}$ Mitzen, "Ontological Security in World Politics".
} 
This article suggests that in the complex period of post-Cold War history in Eurasia, in which collective identities have been radically altered by the break-up of the Union of Soviet Socialist Republics (USSR) and the turbulent establishment of independent states with new national identities, regionalism has served as a strategy to help build and reinforce the 'collective ontological security' of national identities, including those of Kazakhstan and Russia, the case studies that will be looked at in this article. In that respect, it provides an additional legitimising narrative to which regime leaders can anchor their symbolic power, helping them cope with the conflicting identities, norms, values and loyalties that typically unfold in transitional societies. Viewing regionalism in terms of ontological security strategies thus paves the way for considering the effects of regionalism beyond the material performance of regional integration.

However, there is no linear relationship between regional cooperation and increased collective ontological security as the actions needed to ensure the security of one collective national identity may thwart the fulfilment of another. By implication, regional interaction can serve both to shape and reinforce as well as to challenge the ontological security of a collective national identity. Likewise, collective identity boosting may drive regional cooperation strategies, but the need to support collective identities may weaken cooperation when the latter threatens collective ontological security. This ontologicalsecurity explanation for regionalism amongst authoritarian leaders can thus help to account for both the respective drives towards, but also some of the conflict involved in, regional cooperation between authoritarian states. The article sheds further light on the 'virtual regionalism' paradox of why states invest time in underperforming regional bodies whilst offering an additional explanation for the challenge posed by moving beyond weak regional structures in autocratic regions.

This article comprises four sections. The first illustrates how scholars have sought to explain the 'virtual regionalism' paradox to date. The second section discusses ontological security conceptually and sets out the methodological approach and assumptions that underpin the article. The third section discusses the 'identity crises' thought to have beset Russia and Kazakhstan since the collapse of the USSR and the way different strategies of regional cooperation have been employed to build and shape collective identity in response. The 
fourth section documents how the regional level presents both opportunities and risks for bolstering ontological security.

\section{Regionalism and regime-boosting}

Over the last decade, regional organisations have been increasingly studied also as instruments enhancing regime security in authoritarian states.7 Roy Allison, for example, has identified how regional cooperation in Central Asia offers "protective integration", which refers to "a form of collective political solidarity with Russia against international political processes or agendas that are interpreted as challenging politically incumbent regimes". ${ }^{8}$ Similarly, referring to sub-Saharan Africa, Fredrik Söderbaum has described the "regime-boosting" features of regionalism that aim "to strengthen the status, legitimacy and the general interests of the political regime (rather than the nation-state per se)" ${ }^{\prime 9}$ Söderbaum argues that regionalism can be used as "an image-boosting instrument"10 that allows leaders collectively to support one another and their regimes; furthermore, regional events present an image of national leaders fully in charge of their sovereign states.

Drawing on different strands of literature, both on regionalism per se and how authoritarian rule unfolds internationally - and regionally, it is possible to identify four regimeboosting mechanisms by which regional bodies reinforce domestic elites:

- emulation and localisation of international (allegedly or perceivably) legitimate practices,

- creation of façade-legitimating devices,

- delegitimation of Western norms and advancement of alternative values, and

\footnotetext{
${ }^{7}$ Following a rather different path, the link between the membership to certain regional organisations and the resilience or consolidation of the authoritarian regimes of their respective members has been studied not in terms of causality (membership strengthens autocracies) but rather of precondition: "the clustering of nondemocracies within certain organisations may result from the fact that [...] autocracies should find easier to cooperate with each other than with other regimes [...] or that authoritarian countries are less frequently admitted into international organisations created by democracies". Libman, "Supranational Organisations", 133-4.

${ }^{8}$ Allison, "Virtual Regionalism, Regional Structures", 185.

9 Söderbaum, "With a Little Help", 6; and "Modes of Regional Governance in Africa".

10 Söderbaum, "With a Little Help", 7.
} 
- material support. $^{11}$

The first mechanism can be observed, for example, in Latin America, West and Southern Africa and the former Soviet Union, where regional bodies have adopted structures that closely mirror those of the EU. While perceptions of the EU have been dented since the financial crisis and Brexit, for a time adopting European structures and processes and mimicking the pre-eminent West brought a certain form of prestige and sense of progress. A telling example is the Commonwealth of Independent States (CIS) which declared a commitment to setting regional standards in terms of human rights and democracy in the early 1990s. At that time, the CIS (and its member states) were seeking a place in the international community and trying to acquire the reputation and semblance of a 'proper' regional organisation. In some cases, the reference to the European model was explicitly set down in official documents and statements; in other cases, the influence of the European model was manifest in the acceptance of an emerging 'meta-norm' about the transformative impact of regional organisations and the exercise of hegemony through 'normative power'. ${ }^{12}$

A second mechanism is the establishment of façade institutions. In recent years, a welldeveloped literature has documented the way regional bodies can be used to hide illegitimate practices. The most obvious are regional election monitors who provide contrasting opinions to observers from Western countries. In Eurasia, two organisations the CIS and the Shanghai Cooperation Organisation (SCO) - stand out. Following the 'colour revolutions', where flawed elections triggered uprisings, the CIS sent its own observers to counterbalance Western monitors. The CIS observations uniformly endorsed the (re-)election of incumbents, diverging considerably in the vast majority of cases from those of observers from the Organisation for Security and Co-operation in Europe (OSCE). For example, in 2006, the CIS endorsed the re-election of Islam Karimov in Uzbekistan, claiming that the process was "legitimate, free and transparent", whilst OSCE/Office for Democratic Institutions and Human Rights (ODIHR) observers noted that the elections fell

\footnotetext{
${ }^{11}$ Libman instead refers to five mechanisms of regime-boosting through regional organisations, namely legitimacy provision, economic support, governance transfer, mutual learning of the regimes and impact of private business interests. These mechanisms can be ascribed to either democracy promotion, or democracy diffusion, or a mix of the two. Libman, "Supranational Organisations", 134-5.

12 See Russo, "A 'Potemkin Village'?".
} 
short of both Uzbekistan's OSCE commitments and "international standards for democratic elections". ${ }^{13}$ Similar dynamics have been observed in numerous elections in the region. ${ }^{14}$

Third, regional fora provide an additional opportunity for authoritarian regimes to collectively delegitimatise Western values and advance alternative norms. Indeed, both the $\mathrm{CIS}$ and SCO are often used to contest Western perceptions of legitimacy and open up normative space for alternative models of political order. Both organisations promote a pluralism in international affairs that provides space for autocratic states to solidify their rule and reject contrasting models. For example, reflecting the so-called 'Shanghai Spirit', a set of common norms and understandings held by SCO members, the SCO 'Declaration on the fifth anniversary of the Shanghai Cooperation Organisation' celebrates the "diversity of civilization[s] and model[s] of development", highlights "differences in cultural traditions, political and social systems, values and model[s] of development" and notes that "[m]odels of social development should not be 'exported'"'. ${ }^{15}$ The effect is a collective delegitimation of 'foreign interference' and a collective legitimation of the principle of each regime's right to self-determination. ${ }^{16}$

Fourth and finally, regional projects and associated interactions can provide material support that benefits authoritarian elites. For example, during the Arab Spring, the richer members of the Gulf Cooperation Council (GCC) provided financial support to less well-off members to assist them with new public spending pledges. ${ }^{17}$ Along similar lines, in September 2011, the Collective Security Treaty Organisation (CSTO) conducted military exercises that also trained the group's militaries in preventing possible popular uprisings. On that occasion, CSTO's Secretary General, Nikolai Bordyuzha, declared that the organisation had extended its mission, including the management of internal upheaval in member countries and the restoration of public order. ${ }^{18}$

\footnotetext{
${ }^{13}$ Cited in Fawn, "Battle over the Box", 1144.

${ }^{14}$ Cooley, Great Games, Local Rules.

${ }^{15}$ SCO, Declaration on the Fifth Anniversary of the Shanghai Cooperation Organization, Shanghai, 2006, http://eng.sectsco.org/load/19768o/.

16 Jackson, "The role of external factors".

17 Yom, "Authoritarian Monarchies", 60.

${ }^{18}$ Piras and Russo, "Democratic Diffusion Failures".
} 
As seen, when referring to authoritarian promotion/diffusion through regional organisations, post-Soviet regionalisms provide several empirical examples. ${ }^{19}$ Looking at the regional organisations that have emerged in the former Soviet area from this angle of authoritarian regime boosting helps in reconsidering and understanding their role and performativity. Indeed, while post-Soviet regionalisms have often been considered at different times as dysfunctional and non-effective, their effects should be assessed not only in terms of their stated functions but also in terms of the regime boosting practices they convey $^{20}$. The respective literature too often suggests that post-Soviet regionalisms are equal to their institutional embodiments, that is, regional organisations that have proliferated in the former Soviet area. Post-Soviet regional organisations are themselves often referred to as unsuccessful projects that have failed to stimulate further integration or other forms of regional governance..$^{21}$ In other words, scrutiny beyond regionally-scaled policymaking processes and outputs seems to be rare. Moreover, counting the number of regional organisations, looking at their institutional design and/or their formal and codified expressions, and interpreting them solely in terms of power politics do not seem to take into consideration the whole problematique. ${ }^{22}$ As a result, other conceptual grounds have to be broken, grounds that acknowledge the peculiarities of the post-Soviet region ${ }^{23}$ - without straying into exceptionalism.

\section{Ontological security and regionalism: concepts and methods}

While the regime-boosting effects described above have been highlighted in the literature, a fifth dimension - the opportunity that regionalism provides for reinforcing the ontological security of core political support bases - remains under-examined. Yet, opportunities to shape and bolster collective ontological security represent an important boon for authoritarian leaders, irrespective of the functional effectiveness of the regional bodies. As will be described below, regionalism, which offers a means both of expressing collective identity at the national level and of establishing, and in some cases codifying, the recurring

\footnotetext{
20 See for example Libman and Obydenkova, "Informal governance and participation".

${ }^{21}$ See for example Kubicek 2009.

22 Russo, Regions in Transition.

${ }^{23}$ Libman and Vinokurov, "Holding-Together Regionalism".
} 
patterns of interactions with important neighbouring states that ensure this collective identity over time can play a key role in ensuring collective ontological security.

This section outlines the concept of collective ontological security in the International Relations (IR) field, and highlights the importance of the regional context for the shaping of national identity and its security (collective ontological security). It also discusses the methodological approach and assumptions of the article.

The notion of 'ontological security' has added an important conceptual apparatus to discussions of security in International Relations. At the level of individual psychology, 'ontologically security' refers to a person's need for a stable understanding of his/her selfidentity and, importantly, confidence in the continuity of this self-identity and the ability to reproduce it over time. ${ }^{24}$

The preservation of an individual's ontological security is nonetheless a deeply social phenomenon resting often on the collective identities the person feels a part of. Indeed, individuals are strongly attached to the cognitive stability offered by the collective identity that is shared intersubjectively within the societies in which they live. ${ }^{25}$ Correspondingly, a number of scholars have argued that ontological security can and should be analysed at the collective level including, most importantly for IR, the level of the state. ${ }^{26}$ As Steele has argued, the drive to minimise ontological insecurity is so strong that it can override otherwise rational considerations, with states engaging in physical insecurity inducing or economically detrimental activities in their attempts to reinforce ontological security. ${ }^{27}$

Collective understandings of identity are defined in conjunction with or in opposition to other communities - the most important of which, at the international level, are other states. The 'routineisation' of relations and practices with other groups (including statestate relations) serves to "help maintain identity coherence for each group, which in turn provide individuals with a measure of ontological security". ${ }^{28}$

\footnotetext{
${ }^{24}$ Mitzen, "Ontological Security in World Politics", 342.

25 lbid., 352.

${ }^{26}$ Wendt, "Collective Identity Formation", 385; lbid., 351-2.

27 Steele, "Ontological Security in International Relations", 4-5.

${ }^{28}$ Mitzen, "Ontological Security in World Politics", 352.
} 
Regional organisations and states' associated foreign relations with neighbours in their region are essential in this regard. Above all because state identities are shaped intersubjectively with other states. The states that are most geographically proximate and with which a state interacts most often play a disproportionate role in the definition of one's national identity (for example, in the cases described later, defining what 'Kazakhness' is is achieved in part in relation to Eurasianness, Central-Asianness, Post-Sovietness, etc.). As such, the regional level and the ensuing regional interaction is a particularly potent forum for strengthening collective ontological security.

As most strategies for increasing security are determined as responses to perceived insecurities or threats, the methodology employed here involves tracing the key collective identity insecurities generated in Russia and Kazakhstan by the end of the Cold War, and showing how regional cooperation strategies and the elaboration of regional projects and postures by leaders have responded to these challenges. The article uses discourse analysis of speeches and statements made by Russian and Kazakh leaders, as well as representatives of the latest instance of Eurasian integration, the Eurasian Economic Union (EAEU), to evidence how regionalism can be used to build and reinforce identity markers. We assume this is a largely rational and conscious process on the part of state leaders who in both Russia and Kazakhstan have been the key drivers of regional initiatives. While leaders may not speak in terms of ontological security, they are more than aware of the benefits of reinforcing identity markers for citizens and the risks in terms of reduced political support if they do not. Different 'experiments' of Eurasian regionalism have reportedly failed to generate substantial economic and political benefits; yet they have been designed so as to promote non-material benefits from the regime's point of view.

While it is beyond the scope of this article to determine the effectiveness of this strategy, our endeavour is to shed light on how regional institutions and projects in the former Soviet space are often created by member states' rulers as carriers of ontological security provisions. In particular, we focus on the case of the Eurasian Economic Union as it has introduced two elements of novelty with respect to previous instances of post-Soviet regionalism (from the Commonwealth of Independent States to the latest variablegeometry developments): 1) disagreements and differences of opinions among Russian, Kazakh and Belarus presidents Vladimir Putin, Nursultan Nazarbayev and Alexander 
Lukashenko are not hidden behind a façade of consensus and summitry rituality; 2) opposition to the Eurasian Economic Union has emerged in the agenda of groups of dissidents at both the national and transnational levels.

The added value of looking at ontological security is the shift in focus from inter-state legitimation (regimes seek their legitimation before external audiences) to legitimation also vis-à-vis (limited sectors of why limited ?) internal constituencies that may support Eurasian regionalism and consequently their 'founding fathers' for two equal and opposite reasons: narratives manufactured to present Eurasian regionalism provide collective identity anchors; and instances of resistance and contestation of the Eurasian project occurring within regional fora are presented to the public as moments to assert national interests and national distinctiveness against the background of the 'regional whole'.

Ontological security provisions enter the strategic agendas of newly-launched institutions such as the EAEU (as will be shown later), as a way to offer collective structures of selfidentification and narratives to draw on. It is noteworthy that the EAEU has organised two events to promote the fabrication of a Eurasian collective identity and storytelling: in 2014 the Eu rasian Economic Commission (EEC) Press Office, jointly with the Russian Public Relations Association, held a seminar to discuss the specifics of disseminating information about the EAEU and, in the words of the Eurasian Communications Centre Press Secretary, the "formation of a new meta-plot framework";- and in 2015 the EEC and the Russian International Affairs Council organised a summer school to promote the formation of a Eurasian community of experts and journalists specialising in Eurasian integration.

\section{Ontological insecurities in Russia and Kazakhstan}

The collapse of the Soviet Union left both populations and rulers in successor states with several identity problems to solve and identity-based conflicts to appease.

The question of Russian identity has always been difficult to specify. Indeed, straddling not only multiple ethnicities but also continents, defining what is 'Russianness' has been a preoccupation of Russians themselves for centuries. However, following the collapse of the 
Soviet Union, Russia experienced "a crisis of identity and national self-consciousness". ${ }^{29}$ Early debates in the 1990s were dominated by disagreement between two poles: on the one side, 'Westerners' who saw Russia as a 'European/Western' country; ${ }^{30}$ on the other side, 'fundamentalist nationalists' who defined 'Russianness' quite differently, asserting Russia's distinctiveness from the West, arguing that Russia's 'home' was in Eurasia and reaffirming Russia's great power status. ${ }^{31}$

To some extent these issues were temporarily settled by the coming to power of Putin and the success of the so-called 'pragmatic nationalists' who initially took a middle position but have taken a more nationalist stance over time. ${ }^{32}$ However, questions of Russian identity remain open, particularly in relation to several international dimensions: Russia's place between East and West, Russia's relations with its neighbours, and the way in which Russia's 'great power status' should be practiced and attained. As will be described below, regional integration and cooperation provides some answers to these questions, but in somewhat problematic ways for both Russia and its neighbours.

For Kazakhstan, defining a national identity also proved a challenge after the collapse of the USSR. The country emerged from the Soviet Union as host to over 100 nationalities with the Kazakh authorities thus facing a series of major tests: First, how to establish a new, sovereign and independent Kazakh state, which had not existed previously in a Westphalian sense (although the Kazakh Steppe had long been settled by nomadic Kazakhs) Like neighbouring Kyrgyzstan,33 Kazakhstan was developing statehood largely from scratch, not having experienced the (albeit brief) periods of statehood enjoyed by other USSR-successor states such as Georgia, Latvia or Estonia. Second, how to create a harmonious internal social system bridging the divide between ethnic Kazakhs and the ethnic Russians who now found themselves in the new state of Kazakhstan? The legitimacy of Nazarbayev's regime rested on the realisation of these objectives of interethnic harmony, statehood and sovereignty.

\footnotetext{
${ }^{29}$ Kortunov, The Fate of Russia; Light, In search of an identity, 2003.

${ }^{30}$ Light, In search of an identity, 44.

${ }^{31}$ lbid.

${ }^{32}$ Light, "In search of an identity", 45.

33 Cf. Huskey, "National identity from scratch".
} 
Relations with Russia (and with 'Russianness') are central to the post-independence Kazakh identity. Russian nationalistic notions of regional leadership are problematic for Kazakhstan, and independence from major powers on the world stage (including Russia) is a defining feature of Kazakhstan's 'multi-vector foreign policy'. Indeed, Nazarbayev has used Kazakh foreign policy and international positioning as an important tool of identity and legitimacy-shaping. ${ }^{34}$ However, the role that Russia plays in the Kazakh identity is complicated by the sizeable Russian minority in Kazakhstan. The Kazakh regime has in many ways done remarkably well following independence in terms of inter-ethnic accord. Despite the plurality of different ethnic groups in the country, Kazakhstan has mostly avoided the major ethnic tensions seen in neighbouring countries (a feat Russia has not managed).

Yet, post-independence Kazakhstan has seen what some would consider the ethnicKazakhisation of the country, with Kazakh adopted as an official language, new statues erected exulting (ethnic) Kazaks, and street names changed into Kazakh, amongst other things. Many non-ethnic Kazakhs, disturbed by these changes, voted with their feet, with over 1 million leaving the country between 1993 and 1999.35 At the same time, however, Nazarbayev has promoted civic dimensions of nationalism, seeking to form a broad umbrella identity for all Kazakh citizens within which different ethnic groups can co-exist. Indeed, Nazarbayev's role as a moderating figure mediating these potential ethnic tensions is the source of much of his political support. ${ }^{36}$

\section{Russia and Kazakhstan go regional: strategies to seek ontological security}

Both the Russian and Kazakh governments face divergent, but overlapping challenges in terms of building and reinforcing collective ontological security in Eurasia. The situation however is different for Kazakhstan and Russia. In Kazakhstan, the government has had to deliver and build new forms of identity that unify ethnic Kazakhs without alienating ethnic Russians. For Russia, by contrast, there are centuries of national and imperial history to build on and an increasingly nationalist view of Russian history that can be emphasised.

\footnotetext{
${ }^{34}$ Anceschi, "Regime-building, identity-making and foreign policy".

35 Ó Beacháin and Kevlihan, "State-building, Identity and Nationalism", 4.

${ }^{36} \mathrm{lbid} ., 10$.
} 
Regional cooperation offers opportunities for both leaders to build their collective identities, and reinforce them over time.

\section{Russia: major power status, Russia's 'place in the world' and domestic-regional mirroring}

The policies and practices of Eurasian integration allow for (an at least partial) realisation of these sentiments. First, Eurasian integration facilitates regional policies and processes that allow Russian leaders to demonstrate their great power status and regional leadership. Given Russia's position as leader within Eurasian integration projects, the logic of Eurasian integration for Russian elites implies that the "larger the Eurasian Union, the stronger Russia's great power image will be - domestically and internationally". ${ }^{37}$

Second, it answers - or at least diffuses - certain questions about Russian identity and Russia's place in the (post-Cold War) world. As noted above, Russia's identity within the international system has always been uneasy. ${ }^{38}$ While Russia adopted a European orientation following the collapse of the Soviet Union, this perspective has always been questioned, 39 leaving Russia caught between a number of different European/Western and Eurasian identities. In counter this, Putin has highlighted the common civilisational bonds that underpin regional integration efforts in Eurasia. $4^{\circ}$

Third, Eurasian integration - from a Russian perspective - mirrors at the regional level perceptions about the domestic relations between core and peripheral regions (and thus ethnicities) within Russia itself. On this point, the Russian view of Eurasianism, unlike the Kazakh view, seeks to reproduce the internal self-perception of the dominant domestic group at a regional level. The common bonds of distinct Eurasian civilisation do not mean equal status between Eurasian states. The Russian state is often thought (by the Russian presidential entourage) to be the primary force within the ostensive Eurasian civilisational context, and the neo-Eurasianist notions of the Russian leadership are seen as essential and in some way natural to many Russians. That these Eurasianist sentiments are mirrored both in certain strands of Russian nationalism and the official state discourse, adds weight to their application in the context of the Eurasian Union. From the Russian empire to the

\footnotetext{
37 Popescu, Eurasian Union, 19.

$3^{8}$ Sakwa, "Russia's Identity", 957.

39 Tsygankov, "Mastering space in Eurasia", 102.

$4^{\circ}$ Putin, A new integration project.
} 
Soviet Union to the post-Soviet period of today, ethnic Russians within Russia have been encouraged to identify with Russia as a whole rather than with their ethnic group. ${ }^{41}$ This identity nuance sees Moscow and ethnic Russians as indispensable leaders at the centre of two concentric circles - first within Russia itself, and then secondly, within the post-Soviet space. Taken together, in some sectors in Russia these self-perceptions create both an expectation of Russian leadership and an identity-based affinity with political and economic projects that stretch across the Eurasian borders of the newly independent states.

\section{Kazakhstan: sovereignty and prestige, modern statehood and the regional mirroring of a multi-ethnic identity}

One of the most important benefits of regional integration for the Kazakh leadership is the opportunity it offers to demonstrate Kazakh statehood: public expressions of the pragmatic, voluntary, gradual nature of Eurasian integration, and the acceptance of this stance by Russia, provide significant legitimacy-boosting effects for the regime. ${ }^{2}$ The spectre of Russia lies behind many of Nazarbayev's comments on the Eurasian Union. He regularly highlights how the 'mutual' interests of EAEU members have been considered, underlining that Russia has negotiated with and acquiesced to Kazakh demands. This demonstrates, perhaps rhetorically more than in practice, how Russia and Kazakhstan are now equals (unlike the past) and how Kazakhstan is now a fully sovereign nation. Nazarbayev is quite explicit about this at times, stressing how the EAEU "shall strengthen the immutable principles of political sovereignty and independence [and the] cultural and linguistic uniqueness of our peoples".

Furthermore, the Kazakh government's engagement with Eurasian integration is regularly invoked as evidence of the prestige and importance of the Kazakh state, as Nazarbayev's speeches on the Eurasian Union show: "For the first time in history, an economic union with a powerful natural and resource potential, strategically important in terms of global and regional transport, energy and technology systems is being created on the vast expanses of Eurasia". Nazarbayev also stresses how the EAEU encourages cooperation (on mutually beneficial, that is equal terms) with the European Union (EU), thus highlighting how the EAEU is the EU's equal and therefore again, by association, linking Kazakhstan (which he

\footnotetext{
$4^{1}$ Duncan, "Contemporary Russian Identity", 282.

${ }^{22}$ Anceschi, "Regime-building, identity-making and foreign policy", 738.
} 
establishes is at the heart of the EAEU) with the status of the EU and its member states. 43 Events associated with Regional cooperation also offer opportunities here for summitry. ${ }^{44}$ Attendance at such events, with photos of Nazarbayev at the top table often next to Putin reproduced in national news, serve to reinforce the prestige of Kazakhstan as an important country in terms of regional integration.

Finally, Eurasian regional cooperation presents opportunities for the Kazakh leadership to bolster its domestic identity as a multi-ethnic state. Eurasian integration has indeed served to provide a meta-narrative of ethnic harmony in Eurasia that mirrors efforts to do the same domestically. Kazakh neo-Eurasianism has been framed by the Nazarbayev regime as taking the form of a "civilizational dialogue" between East and West: promoting a balanced regional order that harmoniously brings together Eastern and Western cultures is similar to the challenge Kazakhstan faces in terms of developing inter-ethnic tolerance and harmony at the national level. While Nazarbayev himself has noted in speeches how the EAEU "strengthen[s] friendship, good neighborliness and trust between their countries and peoples", 45 the Kazakh government has also publicly drawn links between 'Eurasia' and 'Nazarbayev's' capital city, Astana, noting how he has overseen the development of the capital so that it reflects both European and Asian cultures and styles. ${ }^{46}$ In this sense, Kazakhstan's regional identity as a regional bridge or intermediary supports efforts to build a multi-ethnic identity domestically. This is further enhanced by Nazarbayev's establishment in Astana in 2003 of the 'Congress of the Leaders of World and Traditional Religions', held every three years with the goal of achieving "mutual respect and tolerance between religions, confessions and ethnoses". 47

\section{Ontological security-boosting in the context of Eurasian integration}

The story of the Eurasian project can be recounted in four main periods:

\footnotetext{
43 All quotes in this section up to here from Urazova, Nazarbayev Speaks About Launching.

44 As described by Söderbaum, "With a Little Help".

45 Urazova, Nazarbayev Speaks About Launching.

${ }^{46}$ Mayor's Office of Astana, History of Astana,2016, http://astana.gov.kz/en/modules/material/42

47 Congress of the Leaders of World and Traditional Religions, 2018, http://www.religionscongress.org/content/blogcategory/18/32/lang, english/.
} 
1. "Eurasian union prior to the Eurasian Union", that is, Nazarbayev's initiatives in the nineties. For example, in a speech at Lomonosov Moscow State University on 29 March 1994, the Kazakh President first envisioned the creation of a "new unity" out of a "space that used to be one country"; ${ }^{48}$

2. "The incubation of a measure for measure": the period that goes from the launch of the European Union's Eastern Partnership (targeting some of the countries belonging to the so-called 'overlapping' or 'shared' neighbourhood) to the publication on 3 October 2011 of the article by Putin entitled "A new integration project for Eurasia: The future in the making"; 49

3. "The preparatory works and negotiations": the period that goes from the Declaration on Eurasian Economic Integration to the entry into force of the Treaty on the Eurasian Economic Union (2011-2015), including the development of a proto-enlargement policy targeting Armenia and Kyrgyzstan;

4. The early stages of operation of the Eurasian Economic Union, which correspond to the mandate of the first Chairman of the Eurasian Commission, Viktor Khristenko (2012-2016).

The ontological security provisions were analysed be scrutinising a set of 47 documents (transcripts of interviews and speeches, statements, addresses) related to the establishment and institutionalisation of the Eurasian Economic Union, selected mainly from two websites (www.eaeunion.org; http://kremlin.ru), and then processed usinga discursive approach. These documents come from the last two stages of development.

Both Russian and Kazakh leaders tend to depict the project as aiming at the citizens' wellbeing: accordingly, Putin and Nazarbayev often refer to their domestic constituencies (people, nations, citizens) and to the new material opportunities that stem from the integration process:

\footnotetext{
${ }^{48}$ Nurbekov, "Eurasian Economic Integration 'Will Continue,' Nazarbayev Says".

${ }^{49}$ Putin, "A new integration project for Eurasia".
} 
I am happy to say that there is popular consensus on this idea in Russia. [...] The citizens of our countries should be able to fully assess the benefits of Eurasian integration. (Putin, 29 May 2014) $)^{50}$

It is very important that the public in our countries broadly supports this policy of closer integration. [...] We need to repay this very high level of trust with tangible results and continued improvements in the well-being and living standards of our peoples. (Putin, 10 October 2014) $)^{51}$

While such reference to the citizens may signal a strategy for ontological security, two caveats should be highlighted. On the one hand, the integration process does not provide for the involvement of civil society and the non-governmental sector in the official debate (see below); on the other, Putin himself has specified that the spectacle of Eurasian integration has an ad hoc audience that is not the common people (more targeted by the narratives of the 'Russian world'52), but rather an emerging community of entrepreneurs and businessmen, in addition to experts, officials and members of government:

Taking into account the interests of the business community has become a priority direction for integration cooperation. The Eurasian Economic Commission has established close cooperation with our nations' business associations and is consulting with entrepreneurs on improving the regulatory framework of the Customs Union and the Common Economic Space. [... B] usiness representatives [...] are the co-authors of all these documents. (Putin, 5 March 2014) ) $^{53}$

Moreover, there is common ground as to how the supranational component of integration should be reconciled with sovereignty: both presidents agree that the Eurasian project is rooted in national interests. However, the two presidents tend to emphasize slightly different aspects of the pragmatism enshrined in the EAEU's institutional mission and design. Putin's vision is quite straightforward in this regard: the EAEU should be oriented "to creat[ing] favourable conditions for the development of our economies in order to maintain stability, security and prosperity in Eurasia" [Italics added]. ${ }^{54}$ Therefore, the

\footnotetext{
${ }^{50}$ Press Statements Following the Meeting of the Supreme Eurasian Economic Council, Astana, May 29th 2014, Press Statements Following the Supreme Eurasian Economic Council Meeting, Astana, 29 May 2014, http://en.kremlin.ru/events/president/transcripts/45790.

${ }^{51}$ Summit of the Supreme Eurasian Economic Council (Opening Remarks at the Summit of the Supreme Eurasian Economic Council), Minsk, 10 October 2014, http://en.kremlin.ru/events/president/news/46767. $5^{2}$ Laruelle, The "Russian World", 2015.

${ }^{53}$ Meeting of the Supreme Eurasian Economic Council, Novo-Ogaryovo, 5 March 2014, http://en.kremlin.ru/events/president/news/20377 .

54 Press Statements Following the Meeting of the Supreme Eurasian Economic Council, Astana, 29 May 2014.
} 
ultimate objective is quite conservative and consistent in that respect with the missions of previous experiments of post-Soviet regionalism. Nazarbayev, on the other hand, while underlining the protection of sovereignty and national interests, also accentuates the elements of innovation of the Eurasian project, stressing the aim of modernisation:

We are creating a fundamentally new model for good neighbourly relations and interaction between peoples in the great Eurasian space. Its foundation is the high level of trust, firm friendship, and mutual support between our governments, tested over history. The Eurasian Economic Union means new opportunities, first and foremost for millions of our nations' citizens. 55

At the same time, Nazarbayev's interpretation of the EAEU also contains elements of conservatism:

We are uniting our economic potential for the prosperity of our nations. The union is, first and foremost, economic and does not touch on issues of member states' independence or political sovereignty in the integration process. ${ }^{56}$

In addition, and somehow in contrast to this, Nazarbayev's narrative on the Eurasian project contains a 'romanticizing' element that balances the abovementioned pragmatism: the Union is rooted in traditional relations among the countries involved, and in a long-term vision that he himself has inspired, to the extent that he has recommended the idea of creating an epic and collective memory for the Eurasian Economic Union: "I feel that May 29 is worthy of being memorialised on our calendars as Eurasian Integration Day". 57

A further element of dissonance between Putin's and Nazarbayev's Eurasianist agendas can be found in the way the two presidents frame the role of the EAEU in the international environment: this 'dossier' not only discloses dissimilar understandings of the Union's external projection, but also different ideas about its development path and its 'encounters' with European integration.

In general, we can speak of a 'love/hate' relationship with the European Union, leading to an ambivalent process of 'othering'. ${ }^{8}$ The EU is admittedly acknowledged as a model: the

\footnotetext{
55 Ibid.

56 lbid.

57 Ibid.

$5^{8}$ Wendt defines identification with the 'other' as "a continuum from negative to positive - from conceiving the other as anathema to the self to conceiving it as an extension of the self" (Wendt, "Collective Identity
} 
former Chairman of the Eurasian Economic Commission, Viktor Khristenko, 59 described the European Union as the "most advanced form of integration in the world". ${ }^{\circ}$ However, while it has frequently been defined as a prototype, its fundamental role vis-à-vis the EAEU remains to provide lessons so as to avoid its mistakes. The EU's two faults most frequently identified by officials and representatives of the EAEU are the preference for widening rather than deepening integration, and the shift from an economic and pragmatic rationale to a political and emotional logic of integration.

Furthermore, whereas the competitive co-existence of the two integration processes has been considered a positive incentive for the EAEU's effectiveness, and a dialogue with the EU has been envisioned, any suggestion of overlapping membership has been unsurprisingly - ruled out. The metaphor used by Khristenko in that respect is telling:

- Can it [Ukraine] join both?

- Probably, it would be the best alternative. However, it is impossible to be a member of two customs unions at the same time. It is similar to polygamy (laughing).

- Yes, it's not customary for the Slavs.

- Open polygamy at least (laughing). ${ }^{61}$

Along the continuum of this love/hate relationship with the EU, Putin and Nazarbayev position themselves differently and embody the process of othering in different ways. Both their positions are in line with the general orientation of creating bridges between Europe and Asia, avoiding any official discourse about an either/or choice between European and Eurasian integration, which are considered complementary. However, for Russia there is a direct link between the EU's involvement in its Eastern neighbourhood, the fragmentation of the 'near abroad' and the crisis in Ukraine, which makes the encounter between the two integration processes a sensitive and not univocally positive matter:

\footnotetext{
Formation", 386). See also Neumann, "Self and Other in International Relations"; Reinke de Buitrago, "Introduction: Othering in International Relations", xxvii.

59 On 1 February 2016, Armenia's former Prime Minister, Tigran Sargsyan, took the Chair.

${ }^{60}$ V. Khristenko, "Decisions are taken by the Commission on a collegial basis", Kazakhstanskaya Pravda, 12 May 2012.

${ }^{61}$ Vedomosti, Interview with Victor Khristenko: "The efficiency of integration within the Customs Union determines the attitude of other states to integration within the CES", 19 December 2012.
} 
We feel that this kind of open market is very dangerous for us; it is unacceptable at today's stage of our economic development. [...]Ukraine is required to implement the European Union's technical regulations within its territory. [...] But Ukraine is not joining as a full member, and I don't think there are any loans or any sort of benefits for it. ${ }^{62}$

EU-EAEU relations are also intimately intertwined with various ideas about EAEU's international dimension, as well as the direction in which to advance in the future. Nazarbayev seems to consider the EAEU one of the carriers moving his country away from the Central Asian peripheries and towards a globalised position. 63 Putin's ambition, on the other hand, is to make the EAEU itself a new pole of international politics. "Wherever I go and whomever I meet - everyone wants to know how to establish relations with the new Eurasian Union." 64

From these two subtle differences portraying EAEU's international actorness flow two moderately dissimilar positions on how to develop the Union further. In contrast to Putin's overstressed enthusiasm vis-à-vis the Union's global outreach, Nazarbayev's position is more prudent ${ }^{65}$, and is shared by a number of EAEU officials and representatives. ${ }^{66}$

\footnotetext{
62 Press Conference Following the Meeting of the Supreme Eurasian Economic Council, Minsk, 24 October 2013, http://en.kremlin.ru/events/president/transcripts/19485.

63 "Astana's history already includes bright pages in international events. These include the Congress of Leaders of World and Traditional Religions, the OSCE summit, the Shanghai Cooperation Organisation summit, meetings of the Organization of Islamic Cooperation and other international organisations. We are preparing to host the Expo 2017 World Exhibition here" (Press Statements Following the Meeting of the Supreme Eurasian Economic Council, Astana, 29 May 2014).

${ }^{64}$ Press Statements Following the Meeting of the Supreme Eurasian Economic Council, Astana, 29 May 2014.

65 "We are therefore very cautious in our approach to taking in new members. The working group first needs to study the economic level in the prospective member country, the level of reforms that have been carried out, and how well suited our economies are to each other in integration terms" (N. Nazarbayev, Press Conference Following the Meeting of the Supreme Eurasian Economic Council, Minks, 24 October 2013).

66 "Depth is similar to roots. No leaves will grow without them. A blow of wind will crush the tree! Large-scale expansion of the union requires a considerable depth of integration" (Interview by Victor Khristenko to Vedomosti: "The efficiency of integration within the Customs Union determines the attitude of other states to integration within the CES", 19 December http://www.eurasiancommission.org/en/nae/news/Pages/19-12-2012.aspx); "Currently, overleaping certain stages or incomplete achievement of the goals, which have already been set, and passing to new goals would be dangerous. The EU experience shows that rush can result in great problems at a later stage" (Interview by Andrei Slepnyov to Interfax News Agency: "The New Eurasian Economic Union will not be a simple sum of today's legal framework and agreements reached", 25 December 2012, http://www.eurasiancommission.org/en/nae/news/Pages/25-12-2012-2.aspx); "We are moving step by step. In order to avoid that the integration building is swept away by the first hurricane, we need depth, we need a solid foundation" (Ogonyok, "Interview with Viktor Khristenko" 28 September 2015, http://www.eurasiancommission.org/en/nae/news/Pages/29-09-2015-4.aspx).
} 
Against this background, there is however an interesting point of convergence between the two narratives: that is, the identification of the Union as the acme of the presidents' political endeavours to reorganise the former Soviet region. ${ }^{67}$

The pace, nature and certain peculiarities of this movement are a thing to be discussed by the presidents. [...] A priori, they play a definitive role. At the current stage of this project, the presidents play not only a role of the bearers of political will, but also those of the main law maker. ${ }^{68}$

We are glad that the "path" for making decisions at the current integration stage is much shorter than the common one; in fact, presidents act as lawmakers. Though there is huge responsibility for the preparation of decisions. ${ }^{69}$

\section{CONCLUSION}

There are number of ways in which regional cooperation in Eurasia serves to boost ontological security in Kazakhstan and Russia. Eurasian integration impacts on two essential dimensions of collective identity and national self-perception, namely: a) questions of national progress and development and $b$ ) questions pertaining to regional dynamics. In the first instance, regional cooperation via the Eurasian Economic Union presents a collective opportunity to boost ontological security in each respective country in ways that are mutually supportive (or at least not conflicting). The second dimension is more complex however, with Russian collective identification as a great power and regional leader clashing with Kazakh perceptions of growing sovereignty and independence.

As the case studies above have shown, the approaches of Russia and Kazakhstan to Eurasian integration may boost ontological security. Leaders in both countries have adopted strategies towards regional cooperation that have the potential to bolster collective ontological security in their respective countries. However, the interaction of these strategies, given their contradictions, has the potential to do the opposite. Collective

\footnotetext{
${ }^{67}$ See also the interview by Andrei Slepnyov, where he stated that "the Presidents agreed to [...]personally address all road forks of integration, because integration, as can be seen from the experience of our EU neighbors, requires ongoing attention and political decisions by the leaders. The bureaucratic machines are largely inclined to protect their own interests, thus decelerating integration; hence, political will is needed to keep the process running at the required pace ("The New Eurasian Economic Union will not be a simple sum of today's legal framework and agreements reached", Interfax News Agency, December 25 $5^{\text {th }}$ 2012).

${ }^{68}$ Kazakhstanskaya Pravda, Interview with Victor Khristenko: "Decisions are taken by the Commission on a collegial basis", 12 May 2012.

${ }^{69}$ Ogonyok, "Interview with Viktor Khristenko".
} 
ontological security in Russia requires playing the role of regional leadership, demonstrating great power status and establishing a concentric circles model of politics across the Eurasian space. However, this approach clashes with Kazakhstan's selfperceptions of sovereignty and national statehood. Kazakhstan can react to boost its own ontological security by demonstrating its independence and 'state-ness', but in so doing risks undermining its own goals of inter-ethnic harmony across the Eurasian space, which is supposed to mirror that within Kazakhstan itself. This does not mean that Russia and Kazakhstan cannot cooperate, but it means that even a mutually agreed and accommodating position (such as the current status quo) may raise difficult ontological insecurities. By contrast, as the discussion of Kazakh celebrations of statehood demonstrates, regional tensions can be used to bolster collective ontological security, but at the expense of regional integration. While these examples refer to Eurasia, they raise a number of observations that are potentially relevant for other regions. First, regionalism can play a role in both strengthening and undermining ontological security. Because ontological security is concerned fundamentally with identity over time and because, as described, identity plays a key role in the development of legitimacy, regional integration and cooperation have the potential to both strengthen and undermine state legitimacy, including that of authoritarian states. The crucial dimension here is the impact of regionalism on ontological security. As noted in the Eurasian case, regional cooperation that reinforces identity and ontological security can boost state legitimacy, whereas regionalism that fosters a fundamental challenge to identity creates a situation in which a state must either reject or limit cooperation (so as to re-establish ontological security), or continue cooperating under terms that challenge ontological security, which may have negative repercussions for state leaders.

Notes on Contributors

Alessandra Russo is Post-doctoral Researcher at Sciences Po Bordeaux, Pessac, France. Edward Stoddard is Principal Lecturer at the University of Portsmouth, Portsmouth, UK. Email: ed.stoddard@port.ac.uk Twitter: @StoddardEd 


\section{References}

Allison, R. "Virtual Regionalism, Regional Structures and Regime Security in Central Asia". Central Asian Surve, 27, no. 2 (2008): 185-202.

Anceschi, L. "Regime-building, identity-making and foreign policy: neo-Eurasianist rhetoric in post-Soviet Kazakhstan". Nationalities Papers: The Journal of Nationalism and Ethnicity 42 , no. 5 (2014): 733-49.

Bohr, A. "Regionalism in Central Asia: New Geopolitics, Old Regional Order". International Affairs 8o, no. 3 (2004): 485-502.

Börzel, T. "Comparative Regionalism: A New Research Agenda", KFG Working Paper No. 28. Berlin: Freie Universitaet Berlin, 2011. http://userpage.fuberlin.de/kfgeu/kfgwp/wpseries/WorkingPaperKFG_28.pdf.

Buzan, B., and O. Wæver. Regions and Powers: The Structure of International Security. Cambridge: Cambridge University Press, 2003.

Collins, K. "Economic and Security Regionalism among Patrimonial Authoritarian Regimes: The Case of Central Asia". Europe-Asia Studies 61, no. 2 (2009): 249-81.

Cooley, A. Great Games, Local Rules: The New Great Power Contest in Central Asia. Oxford: Oxford University Press, 2012.

Croft, S. "Constructing Ontological Insecurity: The Insecuritization of Britain's Muslims". Contemporary Security Policy 33, no. 2 (2012): 219-35.

Darwich, M. The Ontological (In)security of Similarity: Wahhabism versus Islamism in Saudi Foreign Policy. GIGA Working Paper No. 263. Hamburg; GIGA, 2014.

Duncan, P. "Contemporary Russian Identity Between East and West". The Historical Journal 48, no. 1 (2005): 277-94.

Fawcett, L., and H. Gandois. "Regionalism in Africa and the Middle East: Implications for EU Studies". Journal of European Integration 32, no. 6 (2010): 617-36.

Fawn, R. "Battle over the Box: International Election Observation Missions, Political Competition and Retrenchment in the Post-Soviet Space". International Affairs 82, no. 6 (2006): 1133-53.

Huskey, E. "National identity from scratch: Defining Kyrgyzstan's role in world affairs". Journal of Communist Studies and Transition Politics 19, no. 3 (2003): 111-38. 
Jackson N. "The role of external factors in advancing non-liberal democratic forms of political rule: a case study of Russia's influence on Central Asian regimes". Contemporary Politics 16, no. 1 (2010): 101-18.

Kinnvall, C. "Globalization and Religious Nationalism: Self, Identity, and the Search for Ontological Security." Political Psychology 25,no. 5 (2004): 741-67.

Kirschner, V., and S. Stapel. "Does Regime Type Matter? Regional Integration from the Nation State's Perspectives in ECOWAS". In Roads to Regionalism: Genesis, Design and Effects of Regional Organizations, edited by T. Börzel, L. Golterman, M. Lohaus and K. Striebinger: 141-57. Farnham: Ashgate, 2012.

Kortunov, S. The Fate of Russia: Several Observations on "New" Russian Identity. Stanford University, 1998. http://web.stanford.edu/group/Russia20/volumepdf/Kortunov.pdf.

Kubicek , P. "The Commonwealth of Independent States: An Example of Failed Regionalism". In Globalising the Regional, Regionalising the Global, edited by R. Fawn: 237256. Cambridge: Cambridge University Press, 2009.

Laruelle, M. The "Russian World:" Russia's Soft Power and Geopolitical Imagination. Center on Global Interests, 2015. globalinterests.org/wp-content/.../FINAL-CGI_RussianWorld_Marlene-Laruelle.pdf.

Libman, A. "Supranational Organisations: Russia and the Eurasian Economic Union". In Autocratic and Democratic External Influences in Post-Soviet Eurasia, edited by A. Obydenkova and A. Libman: 133-58. Surrey and Burlington: Ashgate, 2015.

Libman, A., and A. Obydenkova. "Informal governance and participation in non-democratic international organizations". The Review of International Organizations 8, no. 2 (2013): 22145 .

Libman, A., and E. Vinokurov. Holding-Together Regionalism: Twenty Years of Post-Soviet Integration. Basingstoke: Palgrave Macmillan, 2012.

Light, M. "In search of an identity: Russian foreign policy and the end of ideology". Journal of Communist Studies and Transition Politics 19, no. 3 (2003): 42-59.

Mitzen, J. "Ontological Security in World Politics: State Identity and the Security Dilemma". European Journal of International Relations 12, no. 3 (2006): 341-70.

Neumann, I. "Self and Other in International Relations". European Journal of International Relations 2, no. 2 (1996): 139-74.

Nurbekov, A. "Eurasian Economic Integration 'Will Continue,' Nazarbayev Says". The Astana Times, 2 April 2014. 
Ó Beacháin, D., and R. Kevlihan. State-building, Identity and Nationalism in Kazakhstan: Some Preliminary Thoughts, Dublin City University Working Paper Series 1/2011. Dublin: Dublin City University, 2011.

Padgett, D. K. "There's no place like (a) home: Ontological security among persons with serious mental illness in the United States". Social Science \& Medicine 64, no. 9 (2007): 192536.

Piras, E., and A. Russo. "Democratic Diffusion Failures or Successful Authoritarian Protection? Central Asian Undeclared Policies vis-à-vis the 'Arab Spring'." Italian Political Science Review 48, no. 3 (2014): 247-66.

Popescu, N. Eurasian Union: the real, the imaginary and the likely, EUISS. Chaillot Paper No.132. Paris: European Union Institute for Security Studies, 2014.

Putin, V. A new integration project for Eurasia: The future in the making. Russian EU Mission, 2011. http://www.russianmission.eu/en/news/article-prime-minister-vladimir-putin-newintegration-project-eurasia-future-making-izvestia-3-\#sthash.pOrrVynı.dpuf

Reinke de Buitrago, S. "Introduction: Othering in International Relations: Significance and Implications". In Portraying the Other in International Relations: Cases of Othering, Their Dynamics and the Potential for Transformation, edited by S. Reinke de Buitrago. Newcastle: Cambridge Scholars Publishing, 2012.

Russo, A. Regions in Transition in the Former Soviet Area: Ideas and Institutions in the Making. Basingstoke: Palgrave, 2018.

Russo, A. "A 'Potemkin Village'? Governance Transfer by the CIS". In Governance Transfer by Regional Organizations, edited by T. Börzel and V. van Hüllen: 141-58. Basingstoke: Palgrave Macmillan, 2015.

Sakwa, R. "Russia's Identity: Between the 'Domestic' and the 'International'". Europe-Asia Studies 63, no. 6 (2011): 957-75.

Söderbaum, F. "With a Little Help From My Friends": How Regional Organizations in Africa Sustain Clientelism, Corruption and Discrimination. University of Gothenburg, 2010. http://www.pol.gu.se/digitalAssets/1316/1316597_soderbaum.panel1.pdf.

Söderbaum, F. "Modes of Regional Governance in Africa: Neoliberalism, Sovereignty Boosting, and Shadow Networks". Global Governance 10, no. 4 (2004): 419-36.

Steele, B. Ontological Security in International Relations: Self-Identity and the IR State. Abingdon: Routledge, 2008.

Tsygankov, A. "Mastering space in Eurasia: Russia's geopolitical thinking after the Soviet break-up". Communist and Post-Communist Studies 36, no. 1 (2003): 101-27. 
Urazova, D. Nazarbayev Speaks About Launching Eurasian Economic Union. Tengrinews, 2014. https://en.tengrinews.kz/politics_sub/Nazarbayev-speaks-about-launching-EurasianEconomic-Union-258082/.

Wendt, A. "Collective Identity Formation and the International State". The American Political Science Review 88, no. 2 (1994): 384-96.

Yom, S. L. "Authoritarian Monarchies as an Epistemic Community: Diffusion, Repression and Survival during the Arab Spring". Taiwan Journal of Democracy 10, no. 1 (2014): 43-62. 